\title{
Bank Credits to the Private Sector: Potency and Relevance in Nigeria's Economic Growth Process
}

\author{
Prince C. Nwakanma ${ }^{1}$, Ikechukwu S. Nnamdi ${ }^{1} \&$ Godfrey O. Omojefe ${ }^{1}$ \\ ${ }^{1}$ Department of Finance and Banking, University of Port Harcourt, Nigeria \\ Correspondence: Prince C. Nwakanma, Department of Finance and Banking, University of Port Harcourt, Nigeria. \\ E-mail: nwakanma5@yahoo.com
}

Received: February 7, 2014

Accepted: February 22, 2014

Online Published: March 10, 2014

doi:10.5430/afr.v3n2p23

URL: http://dx.doi.org/10.5430/afr.v3n2p23

\begin{abstract}
This study aims at evaluating the nature of long-run relationship existing between bank credits to the private sector of Nigeria's economy and the nation's economic growth as well as the directions of prevailing causality between them. Covering the period 1981 and 2011 (31 yrs), the Autoregressive Distributed Lag Bound (ARDL) and Granger Causality techniques were employed. The results indicate significant long-run relationship between the study variables but without significant causality in any direction. Measures including development of relatively long tenured bank credit products as well as enforcement of credit regularization contracts are recommended in order to strengthen the operations of banks in Nigeria and their expected roles in financing entrepreneurship.
\end{abstract}

Keywords: Bank credits, Credit disbursement, Private sector, ARDL, Economic growth process

\section{Introduction}

The empirical relevance of the capacity of banks to accelerate economic growth process of nations has attracted diverse and varied debate in financial economics literature. Financial intermediation function consequently brings to the fore, the mechanism for anticipated role of banks in the economic growth process of nations. Popkova et al (2010) view economic growth as the capacity of an economy to advance the periodic production of goods and services through the employment of available stock of capital and other factors of production. The quantum and quality of accumulated capital stock is increased through retained earnings of economic units and credit resources availed by financial institutions. Credits within the purview of this paper, serve as a vehicle through which financial resources advanced by banks to entrepreneurs are transmitted for additional capital formation thereby, facilitating increased investment and resultantly, economic growth.

One of the early expositions of the capacity of financial institutions to support sporadic advances in output production through provision of credit facilities to innovative entrepreneurial groups could be traced to Schumpeter (1934). The study concludes that where enterprise leads, finance follows. Meier and Baldwin (1980), also remark that in Schumpeterian analysis of economic growth process, entrepreneurs secure project funding not from savings out of current income, but from the credit creating banking system.

The capacity of banking enterprise to provide potentially unlimited funding outside household savings and corporate internally retained earnings provides basis for ever expanding productive entrepreneurial activities, thus causing the economic growth process to experience quantum leaps. Even in the recent past, Schumpeter's view has been significantly re-enforced by Ngai (2005), who argues that in a significant number of less developed economies characterized by prevalence of weak capital markets, bank credit to the private sector still constitutes an important source of funding valuable number of productive investment projects. Finance thus, serves as an essential lubricant and acts as an integrating factor with respect to all other factors of production.

To validate the need for substantial flow of financial resources, varied forms of financial institutions have evolved over time. Bhole (2006) argues that the level of development and sophistication of a nation's financial sector serves as an essential index for the assessment of her level of economic growth. This position is also corroborated by Coricelli (2008) who posits that the financial sector acts as a shock absorber to the economic growth process and consequently concludes that the less developed economies experience relatively lower output levels principally because of the relatively lower levels of development and sophistication of their financial sectors. Economic growth has remained substantially, a core objective of national governments irrespective of the level of development. Bhole 
(2006) comments that while the developed economies are currently concerned with the problem of sustaining and possibly, advancing their tempo of economic progress, the less developed economies are significantly saddled with the core issue of jump-starting or at best, accelerating their economic growth rates.

Okereke and Anyanwu (2008), Okpara and Nwaoha (2010) as well as Chuku (2010) all allude to the fact that implementation of most monetary polices hinges on the premise that the domestic banking and financial institutions could be influenced, either through market related or regulatory measures to operate in certain directions hoped to yield targeted objectives. This substantially, alludes to Patrick (1976) who views financial institutions as having capacity to play dual roles - demand following and supply leading.

Accordingly, Nigerian banks perform varied functions. Lending part of their mobilized deposits to entrepreneurs constitutes a glaring aspect of their intermediation function. Depending on prevailing statutory regulations, (loan/deposit ratio, cash ratio, liquidity ratio, credit ceilings, single obligor rule etc), banks extend cash related credits to entrepreneurial ventures for investment purposes. The above mentioned statutory regulations not withstanding, deposit money banks also, undertake other service related functions which range from assumption of significant contingent liability exposures (performance bonds, guarantees, indemnities etc) to the facilitation of several forms of international and professional service transactions for their clients among others. The influence of bank operations on the economic progress of nations has been viewed from various perspectives. While some studies are concerned with the effects of intermediation capacity indicators on economic growth of nations, others tend to evaluate the effects of sectoral bank exposures to entrepreneurial ventures on economic growth.

Accordingly, Sanusi (2011) views the Nigerian banking industry as a veritable instrument for economic advancement, since it has significant capacity to provide the much needed synergy between the various sectors of the economy. Further, the study views banks as conducive agents for implementation of state economic polices as they function through the intermediation process to effectively allocate savings, thereby, improving productivity, credit allocation, identification of entrepreneurs, risk diversification, product innovation and by implication economic growth. Ekpenyong and Acha (2011) examine the contributions of Nigerian banks to economic growth through the employment of four selected financial intermediation variables which include financial deepening ratio, savings ratio, credit ratio and currency ratio. Without providing justification for limiting the study variables to those four among other known intermediation ratios, the study employed co-integration technique to evaluate the nature of long-run relationships that exist between the selected variables and Nigeria's GDP. Evaluated also, are the predictive powers of the explanatory variables with respect to variations in the GDP.

Adopting a generalized ordinary least squares regression technique, Nwanyanwu (2011) finds positive but insignificant relationship between aggregate bank credit to Nigerian entrepreneurs and GDP. The study calls for regulatory authorities to adopt administrative and repressive measures including directed credits and controls, as well as elongation of credit tenures in order to improve on the relationship between bank credits and Nigeria's GDP. Decomposing bank credits into allocations to general commerce, services, production and others, Onuorah and Ozurumba (2013) examine the nature of long-run and causal relationships between sectoral credits and Nigeria's GDP. The results reveal significant long-run relationships, but without any of the sectorally allocated credits Granger causing Real GDP. On the contrary, the GDP was found to Granger cause all of the sectoral credits. Accordingly, the study calls for increased supervision and direction of bank credits to enhance Nigeria's economic growth.

Most of the empirical studies reviewed in this study have approached the subject of relationship between finance and economic growth from the perspective of financial intermediation performance indicators or sectoral distribution of credits within the economy and have largely set out from the point of view that finance is both necessary and good for economic growth. Obviously, categories of profit driven deposit money banks in Nigeria have over the years, held substantial portfolios of cash related exposures to enterprise. Demetriades and Hussein (1996) argue that private sector bank credits are more productive which partly supports Shaw's (1976) advocacy of financial liberalization as opposed to repressive financial policy thrusts.

Essentially, the anticipated development inducing role of financial institutions especially in less developed economies, could explain substantially, continued government credit policy interventions aimed at influencing bank lending to essentially prioritized sectors of the economy. In Nigeria, although economic deregulation was adopted in 1986 through the Structural Adjustment Programme (SAP), the government continued to enforce sectoral allocation of credits. It was however, not until 1992 that guided deregulation of the banking sector was fully implemented. Under the regime of sectoral allocation of credits, operating banks were compelled to advance a stipulated minimum percentage of their overall credit portfolios to specified and prioritized sectors. Evidence of exceeding specified ceilings for less preferred sectors was seriously viewed as infraction with stipulated sanctions. 
In recent times and in accordance with economic liberalization policy dictates, the Nigerian government has in co-operation with the Central Bank of Nigeria, continued to innovate and implement various financial reforms including the 2005 bank consolidation and recapitalization programme in order to fashion out competitive financial institutions that can provide efficient and market dictated services at both micro and macro levels of the economy. These efforts are to ensure that entrepreneurship continues to thrive through substantial and increasing availability of credits and other financial services related products that need to be offered by financial service institutions to advance the growth of the Nigerian economy.

The prevalence of a wide range of disagreements in financial economics literature on the exact nature of the long-run relationship and directions of causality between bank credits to the private sector and economic growth process of nations provides a motivation for this study. While this study represents an attempt to add to the growing volume of Nigerian financial literature, we contend that the annually aggregated cash related credit exposures to the private sector by all categories of deposit money banks could also, constitute rational and reliable basis to explore the empirical interrelationships and directions of causality between Nigeria's economic growth and banks' exposures to the private sector. The above key issues therefore, constitute the key problem of this study.

The time scope for this study covers the period 1981 to 2011 (31 years), while the results are hoped to be of immense benefits to monetary and banking policy managers, deposit money bank operators and all other stakeholders in the Nigerian banking and economic growth enterprise. Having dealt with the introductory section, the rest of this paper is divided into five sections. Section 2 provides the theoretical framework for this study, while section 3 offers a review of empirical and related studies. Section 4 opens with organization of data and methodology adopted, while section 5 deals with presentation of results. Section 6 , presents the discussions reached and recommendations.

\section{Theoretical Frame Work}

Deposit money banks operate within the business environment and essentially, trade on mobilized deposits in addition to other related services. Financial institutions are net liability takers. However, the possible effects of their credit related transactions on the economy could be routed in the theory of financial intermediation and associated hypotheses that attempt to explain the interactions between economic growth and financial developments in the course of national advancement. Ajie (2006) relates financial intermediation to the process of mobilizing saved resources from surplus saving units in the economy by financial intermediaries (institutions) at market determined rates and onward lending of same or part thereof, to efficient spending units for productive investment purposes. Further, the works of Goldsmith (1969), Patrick (1976) and Shaw (1976) among others advocate that effective management of interest rates (price for money) would overtly, provide basis for stimulation of additional savings out of current income. Depending on the direction of interest rates, the quality and quantity of investible funds through savings mobilization will be directly affected. Consequently, economic growth will be correspondingly advanced or stagnated. The theories rest strongly on supply-leading and growth inducing potentials of financial institutions. They attribute differences in economic growth between nations to the disparities in the levels of development and sophistication of financial institutions therein.

However, Goldsmith, Patrick and Shaw's views are in sharp contrast with the position of Robinson (1952), which contends that financial institutions basically function in a demand-following manner being typical handmaids to domestic entrepreneurship thus, responding passively to other factors that account for economic growth within the economy. Essential fall outs of financial intermediation theory remain the possible financially repressive and/or liberalization policies that may be pursued by the state. Repressive policies that include interest rate regulation, directed credits, high reserve requirements, trade restrictions etc, would tend to diminish potentially investible funds and thereby, retard economic growth. Conversely, free market determination of interest rates and removal of regulatory controls would guarantee the release of increased and appropriately priced funds from savers for productive investments thereby, accelerating economic growth.

Patrick (1976) advances a two-way causality analysis between financial sector development and economic growth. First is the "demand-following" hypothesis whereby, financial sector develops in response to growth of business opportunities in the real sector and consequently, survives through rendition of services to the real sector. On the other extreme is the "supply-leading" hypothesis whereby, the financial sector, prior to maturity of the real sector, exists and primarily functions to mobilize and transfer to the real sector, all the idle savings that were holed up in the traditional sector thus, providing investment capital and acting as engine of growth. Advanced states of economic growth are characterized by mutual co-existence and re-enforcement of each other by the financial and real sectors. The relationship becomes contemporaneous and causality runs bi-directionally as opposed to the uni-directional state 
earlier analysed. A state of no significant causality between financial and the real sector is further, both theoretically and empirically possible and is identified as the "Schumpeterian independent hypothesis" stage of economic growth.

Another theoretical link between financial development and economic growth which has received considerable theoretical and policy attention focuses on the potential capacities of microfinance institutions being part of the deposit money banking set up to augment the economic growth process. As outcomes of Shaw (1973) and McKinnon (1973) theses, studies have shown that in the financial deepening process, emergent microfinance institutions do provide micro credits that in turn, improve the incomes and living standards of the "active poor" (hard working low income groups), because of the leverage effects of credit. Microfinance institutions have thus, unlimited potentials to complement and advance substantially, the capital accumulation process. Further theoretical underpinnings for policy-based credits/lending anchors on the fact that in an ideal market, all participants are price takers. Invariably, neither the government, credit institutions nor the borrowers need to influence either the price or quantum of credit. However, following market failure and implied absence of full information, Vittas and Cho (1996) observe that banks tend to favour credit clients with reliable tract records even if other firms tend to present better investment-opportunities. This informs the preference for development of long term business relationships with clients by credit institutions as it offers first hand information on project screening, evaluation of clients' character and integrity, as well as management of credit risks.

\section{Review of Related Studies}

Adeniyi (2006) argues that economies characterized by efficient financial systems tend to have accelerated economic growth relative to those with less efficient financial systems. Evaluating the relationship between financial development and economic growth, Eatzaz and Malik (2009) find that bank credits to the private sector significantly increase the productivity of workers (output per worker), and as such, facilitates long-run economic growth. Prakash (2009) evaluates finance and economic growth in India and finds a bi-directional causal relationship between financial development and economic growth. The study not only confirms evidence of mutual re-enforcement by the study variables within the Indian environment, but evidences a significant level of sophistication of the Indian financial and economic systems. Ahmed (2008) employs modified OLS techniques in evaluating the nature of long-run relationship between economic growth and financial development while employing bank credits to the private sector as a proxy for financial development. The study finds significant positive relationship between financial development and economic growth. In a later study, Kiran et al (2009) apply ratios of bank credit to the GDP and private sector credit to the GDP and find a positive and statistically significant relationship between bank credits and economic growth.

Ighodaro and Oriakhi (2011) evaluate the nature of trivariate causal relationship between financial development and economic growth in Nigeria. Employing data that cover both the pre and post Structural Adjustment Programme (SAP) regimes in Nigeria, the study finds significant long-run relationship between the study variables - ratio of broad money to income, loan deposit ratio, money supply and real gross domestic product. The results implicate the existence of supply leading hypothesis during the pre-SAP era while demand following hypothesis characterized the post SAP era. It concludes that fluctuations in loan deposit ratio and broad money to income may not necessarily affect Nigeria's economic growth.

Obamuyi and Kayode (2012) examine the specific effect of bank lending and economic growth on Nigeria's manufacturing sector over the period 1973 to 2009, (36 years). The study employs manufacturing production as a function of bank lending, lagged value of manufacturing, inflation rate, maximum lending rate, capacity utilization, financial deepening, exchange rate, real gross domestic product and a dummy of shift in financial policy. Employing co-integration and vector error correction techniques, the study finds that manufacturing capacity utilization and bank lending rates significantly affect manufacturing output in Nigeria. On the whole, the study finds as indeterminate, the empirical relationship between manufacturing output and economic growth in Nigeria. However, the study largely neglects the serious problem of power supply and associated high cost of manufacturing in Nigeria arising from the excessive reliance on generators for manufacturing because of poor public power supply - a problem that has forced many firms to re-locate to neighbouring West African countries. A further shortfall of this study is evidenced in the employment of several interrelated explanatory variables (inflation rate, exchange rate and maximum lending rate) as well as the employment of an explanatory variable which the dependent variable constitutes a part thereto, in order to explain the variations in the dependent variable. This is observed in the employment of GDP to explain manufacturing production. The employment of these highly interrelated variables may largely explain most of the inconclusive and/or indeterminate results obtained. 
Okpara (2010) $)^{\text {a }}$ compares the relative potency of financial repression and liberalization policies on both financial development and economic growth in Nigeria during the associated policy regimes. Employing multiple regression and paired comparison test techniques, the results indicate that financial development significantly impacted on Nigeria's GDP during financial liberalization regime. Also, the paired comparison test reveals that financial liberalization caused valued improvement in the growth of Nigeria's GDP.

In another related study, Okpara (2010) ${ }^{\mathrm{b}}$ examines the effect of financial liberalization on selected Macro economic variables - (gross domestic product (GDP), foreign direct investments (FDI), financial deepening, savings and inflation) in Nigeria. The study utilizes the parametric paired sample statistic for t-test and the non-parametric Wilcox signed rank test. Also, it applies discriminant analysis in evaluating the nature and significance of the differences observed in the selected variables pre and post financial liberalization policy regimes. The results indicate that GDP made the highest positive and significant contribution in the discriminant analysis followed by national savings, while FDI contributed negatively and significantly too. On the whole, financial deepening and inflation did not discriminate significantly.

Acrad, Berkes and Panizza (2012) highlight recent fall-outs of global financial crisis which tend to suggest that some countries have oversized financial systems relative to the size of their domestic economy, thus raising the question as to whether there is a threshold beyond which, financial development begins to retard economic growth. The results show that for countries with significant financial deepening, bank credits to the private sector above $80-100 \%$ of GDP, result in a retarding effect on economic growth. The retarding effect accordingly, could arise from the fact that excessive credit growth has the tendency to induce economic volatility and as such, a high probability of financial crisis, as well as the fact that high credit growth could lead to potential resource misallocation.

Murty, Sailaja and Demissie (2012) find a significant long-run relationship between bank credits and economic growth in Ethiopia. Employing the co-integration technique and data over the period 1971/72 to 2010/11, the study concludes that through efficient resource allocation mechanisms and domestic capital accumulation, bank credits positively influence economic growth in Ethiopia. The study calls for creation of more money and capital market institutions in order to accelerate Ethiopia's economic growth. Nuno (2012) applies a dynamic panel data (GMM System Estimator) technique to evaluate the nexus between bank credits and economic growth in the European Union. The study finds that savings promotes growth while inflation and bank credits negatively impact on economic growth. From the results, the study concludes that rapid credit expansions if not properly managed, could lead to banking crisis, weaken the economy, and also, retard both savings and investment in the economy.

Akpansung and Babalola (2011) find significant long-run relationship between private sector bank credits and economic growth in Nigeria. The causality results indicate that a unidirectional causality runs from GDP to private sector bank credits and also, from industrial production to GDP. Lending rates are found to impede economic growth. The study recommends increased bank credits to the private sector at reduced interest rate in order to accelerate Nigeria's economic growth.

Nwakanma and Nnamdi (2012) prioritized corporate sectoral investments in Nigeria's capital market over the period $1984-2009$. The study finds that given sectoral net assets employed for productive investment purposes, the banking sector comes last among the four sectors that contribute significantly to Nigeria's economic growth in this order: petroleum marketing, building materials, packaging and banking.

Gunderson (1976) examines America's economic growth process and explores the roles of various economic sectors. Specific and challenging opportunities were explored by leading entrepreneurs. The multiplier effects of entrepreneurial roles associated with J.P Morgan in finance, Andrew Carnegie in Steel, J. D. Rockefeller in Oil and Edward H. Vanderbilt in rail roads were evident.

Kemp (1978) observes that the banking sector played exceptional roles in the economic growth of Europe and America. While noting that country specifics could vary, the study substantially argues that in the cases of Germany, Britain and United States of America, the banking sector made it possible for mobilization of the required quantum of funds which facilitated the establishment of big plants that embodied the latest techniques as well as acting as conduits for foreign investments. In some of these processes, the banking institutions sometimes, became victims of some other forces as observed during periods of financial/economic crisis and panics. To that extent, the study asserts that banks may speed up economic growth or act as a brake upon it, depending on the prevailing circumstances. Contrary to opinions expressed in most of the studies reviewed above, Levine (1997) as well as Hassan et al (2011) assert that rapid bank credit expansion negatively impacts on economic growth. The studies argue that rapid and uncontrolled expansion in bank credits has the tendency to discourage domestic savings and 
investment. Ultimately, uncontrolled credit expansion exerts pressure on the domestic economy, leads to inflation and thus, correlates negatively with economic growth.

It could be observed from studies reviewed that the exact nature of long-run relationship between banking sector credits and economic growth of nations could differ in terms of country specifics and also, timing. Nigeria is not an exception and the need to consistently evaluate this relationship will not only contribute to the diversified literature, but also goes a long way to justify this study's problem statement.

\section{Organization of Data and Methodology}

\subsection{Data and Variable Description}

Data for this study consist of aggregated annual cash related credit exposures of all categories of deposit money banks to the private sector of the Nigerian economy and real gross domestic product. Published (secondary) data were sourced from Central Bank of Nigeria's Statistical Bulletin duly presented as table 1 below:

Table 1. Real Gross Domestic Product And Aggregate Deposit Money Banks' Credits To The Private Sector In Nigeria (1981-2011), ( $\$$ M).

\begin{tabular}{lll}
\hline Year & $\begin{array}{l}\text { Real Gross } \\
\text { Product (NM) Col.1 }\end{array}$ & $\begin{array}{l}\text { Domestic } \\
\text { Private Sector (NM) Col. } 7\end{array}$ \\
\hline 1981 & 251052.3 & 9294.9 \\
1982 & 246726.8 & 11302.1 \\
1983 & 230380.8 & 12279.40 \\
1984 & 227254.7 & 13189.40 \\
1985 & 253013.3 & 13973.10 \\
1986 & 257784.4 & 18473.10 \\
1987 & 225997 & 21697.70 \\
1988 & 275409.6 & 23851.0 \\
1989 & 295090.8 & 27676.20 \\
1990 & 472648.7 & 33366.20 \\
1991 & 328644.5 & 40953.50 \\
1992 & 337288.6 & 54061.40 \\
1993 & 342540.5 & 106957.30 \\
1994 & 345228.5 & 473893 \\
1995 & 352646.2 & 146625.90 \\
1996 & 367218.1 & 211976.80 \\
1997 & 377830.8 & 444371.40 \\
1998 & 388468.1 & 326463.90 \\
1999 & 393107.2 & 394027.60 \\
2000 & 412332.0 & 580273.20 \\
2001 & 431783.2 & 797478.80 \\
2002 & 451785.5 & 958938.80 \\
2003 & 495007.2 & 1219987.90 \\
2004 & 528576.05 & 1530596.50 \\
2005 & 561931.39 & 2005216.0 \\
2006 & 595821.62 & 2540748.10 \\
2007 & 634251.27 & 4836339.0 \\
2008 & 672202.26 & 7842153.10 \\
2009 & 718977.34 & 7759298.0 \\
2010 & 775525.70 & 9101227.1 \\
2011 & 834160.0 & Dedits to \\
\hline
\end{tabular}

Source: (a) National Board for Community Banks, Annual Reports \& Accounts, various years.

(b) Central Bank of Nigeria, Statistical Bulletin, 2005, \& 2010 \& 2011 (online).

Notes: (1) All Community banks transformed to microfinance banks with effect from 31/12/2006

(2) All Merchant and commercial banks transformed to Universal banks with effect from 31/12/2005 
The relevant economic indicator is the real gross domestic product. Several studies including Aliero et al (2013), Nuno (2012) and Murty et al (2012) employed sectoral distribution of credits in the economy as well as selected financial intermediation indicators as study variables with valuable results. However, Demetriades and Hussein (1996) have exceptionally remarked that bank credits to the private sector of the economy reflect not only better quality and quantity of finance, but also, capture the financing role of deposit money banks in the economy. Conceptually, bank credits to the private sector exclude all forms of credits advanced to the public sector and as observed by Levine and Zervous (1998), as well as Crowley (2008), bank credits to the private sector are approved and disbursed under more stringent conditions which raise their potentials of producing qualitative investment results.

\subsection{Model Specifications}

Nigeria's deposit money banking operations constitute the aggregated activities of previously existing commercial, merchant and community banks. Following the studies of Shabri and Majid (2008) as well as Aliero, Abdullahi and Adamu (2013), the following model is adopted to estimate the interrelationships between bank credits to the private sector and Nigeria's real gross domestic product;

$$
\mathrm{RGDP}_{\mathrm{t}}=\beta_{\mathrm{O}}+\beta_{1} \mathrm{BCPS}_{\mathrm{t}}+\mu_{\mathrm{t}}
$$

Where;

$\mathrm{RGDP}_{\mathrm{t}}=$ Real gross domestic product at time $\mathrm{t}$.

$\beta_{\mathrm{o}}=$ Constant parameter

$\mathrm{BCPS}_{\mathrm{t}}=$ Bank credits to the private sector at time $\mathrm{t}$

$\beta_{1}=$ Vector coefficient of bank credits to the private sector

$\mu_{\mathrm{t}}=$ White noise error, assumed statistically random and independent with zero mean, constant variance and serially uncorrelated.

Uppender (2004), Maddala (2007) as well as Gujarati and Porter (2009) show that majority of macro economic time series data are associated with problems of non-stationarity because the data set may have the peculiar problems of time-varying variance, mean or both, which implies that the time-series data could have fundamental unit root properties. The stationarity properties associated with any given set of time-series data could consequently, be evaluated through the conduct of a unit root test to determine the stationarity or otherwise of the time series macro economic data.

\subsection{Stationarity Test}

Basically a pre-requisite for co-integration procedure, stationarity test as observed by Maddala (2007), has gained wide acceptance for analysis of macro economic time series data with stochastic trends. The unit root properties of each set of time series data need to be determined as a prerequisite for inclusion in co-integration analysis and ultimate evaluation of long-run relationships. Consequently, the existence of a unit root implies non-stationarity of the given time-series data while the converse implies stationarity of the data set thereby, making the data set suitable for inclusion in co-integration analysis.

Detection of the existence of a unit root or otherwise in a time series data could be articulated by a consideration of a variable y with a unit root expressed by a first order autoregressive equation AR (1) as follows;

$$
Y_{t}=\alpha Y_{t-1}+\mu_{t}
$$

Where;

$Y_{t}=$ Dependent variable of choice at time $t$.

$\alpha=$ Coefficient of one period lagged value of dependent variable of choice

$\mathrm{Y}_{\mathrm{t}-1}=$ One period lagged value of dependent variable of choice

$\mu_{t}=$ White noise error term assumed statistically independent and randomly distributed with zero mean, constant variance and serially uncorrelated. 
From equation (2), the modeling procedure for evaluation of the existence or otherwise of unit root for the time-series data is specified generally as follows;

$$
\Delta Y_{t}=\propto_{o}+\propto_{2} Y_{t-1}+\sum_{i=1}^{p} \delta_{1} \Delta Y_{t-1}+\epsilon_{i}
$$

Where;

$\mathrm{Y}_{\mathrm{t}}=$ Variable of choice

$\alpha_{0}=$ Intercept

$\Delta=$ First difference operator

$\alpha_{1}=($ for $i=1$ and 2$)$ and $\delta_{1}$ (for $i=1,2$------ $p$ ) are constant parameters

$\sum \mathrm{i}=$ Stationary stochastic process

$\rho=$ Number of lagged terms chosen by Akaike information criterion (AIC) to ensure that $\sum i$ is white noise.

Following equation (3) above, the implied hypotheses for testing the existence or otherwise of a unit root would consist of the following;

$\mathrm{H}_{\mathrm{o}}: \quad \alpha_{2}=\mathrm{o}$, ie there is a unit root - the time series is non-stationary

$\mathrm{H}_{1}: \quad \alpha_{2} \neq \mathrm{o}$, ie there is no unit root - the time series is stationary.

For decision purposes, when the absolute values of the calculated Augmented Dickey Fuller (ADF) test statistic are higher than those of McKinnon's critical values, the null hypothesis $\left(\mathrm{H}_{0}\right)$ is accepted. This conotes the existence of a unit root in $\mathrm{Y}_{\mathrm{t}-1}$ and $\Delta \mathrm{Y}_{\mathrm{t}-1}$ implying that the time series data are non-stationary and un-integrated at levels i.e. of order zero conventionally expressed as $1(0)$. On the other hand, failure to reject the null hypothesis would necessitate further conduct of stationarity tests on the differenced variants of the time series data in order to achieve stationarity. For further differencing, the generalized model could be achieved through a modification of equation (3) above to accommodate the second differences on lagged first as well as the $\mathrm{k}$ lags of the second differences as follows;

$$
\Delta^{2} Y_{t}=\Psi_{1} \Delta Y_{t-1}+\sum_{i-1}^{p} \emptyset_{i} \Delta^{2} Y_{t-1}+\varepsilon_{t}
$$

For the differenced situation, the corresponding hypotheses for testing are as follows;

$\mathrm{H}_{\mathrm{o}}=\Psi_{1}=\mathrm{O}$, i.e., there is a unit root, implying that the time series is non-stationary.

$\mathrm{H}_{1}=\Psi_{1} \quad \neq \mathrm{O}$, i.e., there is no unit root, implying that the time series is stationary.

On the whole, if the time series are stationary on first differencing, they are said to be co-integrated of order one, expressed as 1(I). If stationarity is achieved on second differencing, the time-series is said to be integrated of order two and expressed as 1(2). Conventionally, the lagged variables introduced into the models serve as control variables and equally function to capture the dynamic nature of the study variables - real gross domestic product and bank credits to the private sector (Akpansung and Babalola, 2011).

\subsection{Estimation of Long-Run Relationship Between Bank Credits To The Private Sector and Nigeria's Gross Domestic Product}

The Autoregressive Distributed Lag Bound (ARDL) technique was employed for estimation of the long-run dynamic relationship between Nigeria's real gross domestic product and aggregate bank credits to the private sector of the economy. Following the works of Pesaran and Shin (1996) and Pesaran and Pesaran (2001), the ARDL technique has numerous advantages over the alternative co-integration technique. Firstly, ARDL offers an exceptional opportunity to estimate the intended long-run relationship even when the macro economic time-series data are non-stationary at $1(0), 1(1)$, or both. The ARDL technique is also, associated with the additional potential of providing meaningful results even when the sample size is relatively small, as well as when the series variables are fractionally integrated.

Accordingly, the ARDL model employed for this study is written as follows;

$$
\begin{aligned}
\Delta \mathrm{I}_{\mathrm{n}} \mathrm{RGDP}_{\mathrm{t}}=\delta_{\mathrm{o}} & +\delta_{1} \mathrm{RGDP}_{\mathrm{t}-1}+\delta_{2} \mathrm{BCPS}_{\mathrm{t}-1}+\Sigma \delta_{3} \Delta \mathrm{I}_{n} \mathrm{RGDP}_{t-1}+\Sigma \delta_{4} \Delta \mathrm{I}_{n} \mathrm{BCPS}_{t-1} \\
& +\mu_{1 t}
\end{aligned}
$$


$\Delta \mathrm{I}_{\mathrm{n}} \mathrm{BCPS}_{\mathrm{t}}=\alpha_{\mathrm{o}}+\alpha_{1} \mathrm{BCPS}_{\mathrm{t}-1}+\alpha_{2} \mathrm{I}_{\mathrm{n}} \mathrm{RGDP}_{\mathrm{t}-1}+\Sigma \alpha_{3} \Delta \mathrm{I}_{n} \mathrm{BCPS}_{t-1}+\Sigma \alpha_{4} \Delta \mathrm{I}_{n} \mathrm{RGDP}$

Where;

$$
+\mu_{2 t}
$$

$\mathrm{RGDP}_{\mathrm{t}}=$ Real gross domestic product at time $\mathrm{t}$.

$\mathrm{BCPS}_{\mathrm{t}}=$ Bank credits to the private sector at time $\mathrm{t}$.

$\Delta \mathrm{I}_{\mathrm{n}} \mathrm{RGDP}_{\mathrm{t}}=$ Differenced natural log value of RGDP at time $\mathrm{t}$.

$\delta_{\mathrm{o}}$ and $\alpha_{\mathrm{o}}=$ Constant parameters

$\Delta \mathrm{I}_{\mathrm{n}} \mathrm{BCPS}_{\mathrm{t}}=$ Differenced natural Log value of bank credits to the private sector at time $\mathrm{t}$

$\Delta \mathrm{I}_{\mathrm{n}} \mathrm{RGDP}_{\mathrm{t}-1}=$ First Lag values of the differenced natural log value of RGDP.

$\Delta \mathrm{In} \mathrm{BCPS}_{\mathrm{t}-1}=$ First Lag values of the differenced natural log value of the bank credits to the private sector.

$\mu_{\mathrm{t}}=$ Error term

\subsection{Error Correction Model (ECM)}

Conventionally, the error correction dynamic of the model (ECM), is captured by the term with summation signs $\left(\sum\right)$. At the same time, the approximate long-run relationship of the model is equally captured by the term with $\left[\delta_{\mathrm{s}}\right]$, which is reflected in the second part of the model.

\section{Presentation of Results}

\subsection{Estimation of Relationship Between Nigeria's Real GDP and Bank Credits to the Private Sector}

To evaluate the empirical relationship between Nigeria's real gross domestic product and bank credits to the private sector of the economy, this section starts with analysis of the descriptive statistics as presented in table 2 below:

Table 2. Descriptive Statistics on Real GDP and Bank Credits to The Private Sector of the Nigerian Economy

\begin{tabular}{llllll}
\hline Variables & Observation & Mean & Standard Deviation & Minimum & Maximum \\
\hline Real GDP & 31 & 422925.3 & 168906.7 & 227254.7 & 834160.0 \\
Bank credits to the private sector & 31 & 1618768 & 2851462 & 9294.90 & 9101227 \\
\hline
\end{tabular}

Source: Authors' Computations Using E-views 7.1

An analysis of the descriptive statistics summary shown in table 2 indicates that the number of observations is 31 , which corresponds to the period covered by the study. The mean values for real gross domestic product and bank credits are 422,925.30 and 1,618,768.00 millions of Naira respectively. Also, while the observed minimum and maximum values for real GDP stand as 227,254.70 and 834,160.00 million Naira respectively, the corresponding minimum and maximum values for bank credits to the private sector stand as 9,294.90 and 9,101,227.00 million Naira respectively. At the same time, the computed standard deviations for real GDP and bank credits to the private sector stand at 168,906.70 and 2,851,462.00 respectively, which show a significant difference in magnitude.

\subsection{Stationarity Tests}

In order to evaluate the empirical nature of long-run relationship between bank credits to Nigeria's private sector of the economy and real GDP, this study commences with the conventional test for stationarity or otherwise of the macro-economic time series variables employed, through the adoption of Augmented Dickey - Fuller (ADF) unit root test. The results of the ADF test are presented in table 3 below:

Table 3. Results of Augmented Dickey - Fuller (ADF) Unit Root Test

\begin{tabular}{llll}
\hline Variable & Level value & Differenced value & Conclusion \\
\hline LRGDP & 0.478686 & $-7.628953 * *$ & $1(\mathrm{I})$ \\
LBCPS & 0.416149 & $-4.732863 * *$ & $1(\mathrm{I})$ \\
\hline
\end{tabular}

Source: Authors' Computations Using E-views 7.1 Software.

Note: $* *$, indicates significance $1 \%$.

From table 3 above, the ADF unit root tests conducted on both levels and first differenced natural log values of real GDP (LRGDP) and bank credits to the private sector (LBCPS) as specified in equation 3 of this study basically show that the series variables are not stationary at their levels. On differencing however, stationarity of the series variables 
was achieved after taking the first difference of their natural $\log$ values at $1 \%$ level of significance. This implies that the series variables are co-integrated of order one, conventionally denoted as 1(I) thereby, constituting sufficient basis for the conduct of co-integration test discussed subsequently for the estimation of the long-run relationship between the study variables.

\subsection{Bound F-test for Co-integration}

With stationarity of the study time-series variables achieved, co-integration tests were performed in accordance with equations (5) and (6) earlier specified to evaluate the nature of long-run relationship existing between the study variables. Table 4 below shows the results of Bound F-test for Co-integration along with the asymptotic critical values;

Table 4. Results of Bound F-test for Co-integration

\begin{tabular}{lll}
\hline Dependent variable & Function & F-statistics \\
\hline LRGDP & LRGDP(RGDP/BCPS) & 4.880760 \\
LBCPS & LBCPS (BCPS/RGDP) & 0.374308 \\
Asymptotic Critical Values & $5 \%$ & $10 \%$ \\
Lower Bound & 3.79 & 3.17 \\
Upper Bound & 4.85 & 4.14 \\
\hline
\end{tabular}

Source: Authors' Computations Using E-views 7.1 software, relying on Persan Critical Value Bounds for F-statistics. The results of the Bound F-test for Co-integration presented in table 4 above show that co-integration only exists when the log of RGDP is employed as the dependent variable. This follows from the fact that the computed F-value for LRGDP (RGDP/BCPS) of 4.880760 is higher than all the lower and upper bound limits at both $5 \%$ and $10 \%$ respectively i.e. $(4.880760>3.79$ and 4.85$)$ and $(4.880760>3.17$ and 4.14$)$. On the converse, no long-run relationship is found when log of bank credits to the private sector (LBCPS) is employed as the dependent variable as its computed F-value of 0.374308 is lower than all the lower and upper bound values at both 5 and 10 percent levels of significance respectively.

\subsection{Estimation of Long-run Coefficient Using ARDL Technique}

Having established the presence of long-run relationship between the study variables on the employment of LRGDP as the dependent variable, we proceed to apply the Autoregressive Distributed Lag (ARDL) technique in order to estimate the empirical long-run relationship existing between the study variables - Nigeria's real gross domestic product and bank credits to the private sector. The results of the ARDL technique are shown in table 5 below;

Table 5. Estimated Long-run Coefficient Using ARDL Approach:

\begin{tabular}{lllll}
\hline Regressor & Coefficient & Std Error & t-ratio & P-Value \\
\hline $\begin{array}{l}\text { Dependent Variable: LRGDP } \\
\text { LBCPS }\end{array}$ & 0.083255 & 0.027786 & 2.999480 & 0.0058 \\
\hline
\end{tabular}

$\mathrm{R}^{2}=0.249962$

D.W $=2.195123$

Source: Authors' Computations Using E-view 7.1.

The ARDL technique results shown in table 5 above indicate estimated positive long-run elasticity of 0.083255 which is in accordance with our expected positive influence of bank credits on private sector economic activities resulting from leverage. It implies that bank credits to the private sector have long run positive influence on Nigeria's real gross domestic product which is significant at $1 \%$ level. Consequently, I percent increase in bank credits to the private sector will be associated with 0.8147 percent increase in real gross domestic product in Nigeria. The coefficient of determination $\left(\mathrm{R}^{2}\right)$ value of 0.249962 implies that variations in bank credits to the private sector of the Nigerian economy would explain 24.9962 percent of variations in Nigeria's real gross domestic product. Also, the Durbin-Watson value of 2.195123 is within acceptable range.

\subsection{Granger Causality Tests}

Given our study variables- bank credits to the private sector and Nigeria's real gross domestic product, there is need to determine the extent to which they lead, lag and/or re-enforce themselves. Sims (1972) as well as Maddala (2007) 
demonstrate that for time series variables $Y_{t}$ and $X_{t}$, the $X_{t}$ series fails to Granger cause $Y_{t}$ if in a regression of $Y_{t}$ on lagged, current and future $X$ 's, the later coefficients turn out to be zero. In a generalized manner, the Granger test is conventionally predicted on the following regression analysis;

Where;

$$
\begin{aligned}
& Y_{t}=\beta_{o}+\Sigma \beta_{i} Y_{t-i}+\Sigma \beta_{\mathrm{u}} \mathrm{X}_{\mathrm{t}-\mathrm{i}}+\mu_{\mathrm{i}} \\
& Y_{t}=\alpha_{o}+\Sigma \alpha_{i} X_{t-i}+\Sigma \alpha_{\mathrm{i}} \mathrm{Y}_{\mathrm{t}-\mathrm{i}}+\mathrm{V}_{\mathrm{i}}
\end{aligned}
$$

$Y_{t}$ and $X_{t}$ constitute the time series variables for testing, $\mu_{t}$ and $V_{t}$ are the idiosyncratic terms which fundamentally, capture all the variations in $\mathrm{Y}_{\mathrm{t}}$ and $\mathrm{X}_{\mathrm{t}}$ that were not included in the lagged values.

Table 6 below presents the results of Granger causality test:

Table 6. Results of Granger Causality Test:

\begin{tabular}{lllll}
\hline Null Hypotheses & Lags & Obs & F-statistics & P-value \\
\hline LBCPS does not Granger cause LRGDP & 2 & 29 & 2.40 .70 & 0.1118 \\
LRGDP does not Granger cause LBCPS & $\sqrt{ }$ & $\sqrt{ }$ & 0.34864 & 0.7092
\end{tabular}

Source: Authors' Computations Using E-view 7.1.

The results of Granger causality test indicate that there is no significant causality in either direction between Nigeria's gross domestic product and bank credits to the private sector as none of the F-statistics values is significant at 0.05 level. Consequently, we accept the null hypothesis in both respects and reject the implied alternate hypotheses correspondingly.

\section{Discussions, Conclusions and Recommendations}

This study has essentially evaluated the nature of long-run relationship between bank credits to Nigeria's private sector and real gross domestic product as well as the direction of causality between them. From the findings, we observe that there is a significant long run relationship between bank credits to the private sector and economic growth in Nigeria, but without significant level of causality. Although a significant long run relationship was established, the fact that no significant level of causality was found between Nigeria's real GDP and bank credits to the private sector conforms to the existence of the Schumpeterian independent hypothesis stage of financial and economic development. The above results could probably be attributed to the fact that money market funds are far more expensive in Nigeria compared with capital market funds. CBN (2007) puts the relative cost of money market compared to capital market funds at 5.23, 4.68, 3.54, 3.5 and 4.1 times between the years 2000 and 2004, which trend has always been in favour of capital market fund sources, hence the continued preference for capital market funds especially by established corporate entrepreneurship in Nigeria.

Also, the frequent incidences of non-performing credit portfolios against which, substantial provisions are periodically made by Nigerian banks might have significantly weakened their capacity to lead activities in the productive sector of the economy. Further, the dominance of matching principle in banks' credit considerations usually culminates into their significant preference for short term self liquidating investments. This trend is counter productive and contrasts sharply with the actual demands of productive real sector entrepreneurship. In view of the above, we recommend that while the government should provide adequate legal framework to ensure contract enforcement hoped to enhance capacity of banks in recovering their credit exposures, further measures should also, be taken by banks to develop more long tenured credit products in order to make their intermediation roles in the economic growth process more significant. Further, lending rates should be reviewed to minimize the significant disparity between money and capital market costs of funds in Nigeria.

\section{References}

Acrad, J. L. Berkes, E. \& Panizza, U. (2012). Too Much Finance? IMF Working Paper, WP/12161, International Monetary Fund, Washington D.C.

Adeniyi, O. M. (2006). Bank Credit and Economic Development in Nigeria: A Case of Deposit Money Banks, Jos Journal of Economics.

Ahmed, A. D. (2008). Financial Liberalization, Financial Development and Growth in Sub-Saharan Africa's Economic Reform: An Empirical Investigation, Centre for Strategic Economic Studies, Victoria University, Austria. 
Ajie, H. A., Ezi, C. T., Akekere, J. \& Ewubare, D. B, (2006). Financial Institutions, Markets and Contemporary Issues, Port Harcourt, Pearl Publishers.

Akpansung, A. O. \& Babalola, S. J. (2011). Banking Sector Credit and Economic Growth In Nigeria: An Empirical Investigation, CBN Journal of Applied Statistics, Vol. 2., No. 2.

Aliero, H. M., Abdullahi, Y. Z. \& Adamu, N. (2013). Private Sector Credit and Economic Growth Nexus In Nigeria: An Autoregressive Distributed Lag Bound Approach, Mediterranean Journal of Social Sciences, Vol. 4, No. 1, (Jan) Doi:10.5901/mjss.2013.V4nlp83.

Bhole, L. M. (2006). Financial Institutions and Markets, New Delhi, Tata-McGraw-Hill Publishing Coy.

Central Bank of Nigeria. (2007). Capital Market Dynamics In Nigeria: Structure, Transaction Cost and Efficiency, 1980 - 2006, Abuja, CBN.

Chuku, A. C. (2010). Monetary and fiscal Policy Interactions In Nigeria: An Application of a State-Space Model With Markov-Switching, CBN Journal of Applied Statistics, Vol. 1, No. 1, (Dec.).

Coricelli, F. (2008). Finance and Growth: When Does Credit Really Matter? Research-Based Policy Analysis and Commentary from Leading Economist, Retrieved on 7/9/2013 from http://www.voxeu.org/index.

Crowley, J. (2008) Credit Growth In The Middle East, North Africa and Central Asia Region, IMF Working Paper, No. $08 / 184$.

Dauda, R. O. S. (2007). The Role of Community Banking System In Nigeria's Development Process: An Appraisal, Journal of Banking, Vol. 2, No. 1, (June).

Demetriades, P. O. \& Hussein, K. (1996). Does Financial Development Cause Economic Growth?: Time Series Evidence from 16 Countries, Journal of Development Economics, Vol. 51, pp. 387-411. http://dx.doi.org/10.1016/S0304-3878(96)00421-X

Eatzaz, A. \& Malik, A. (2009). Financial Sector and Economic Growth: An Empirical Analysis of Developing Countries, Journal of Economic Cooperation and Development, Vol. 30, No. 1

Ekpenyong, D. B. \& Acha, I. A. (2011). Banks and Economic Growth in Nigeria, European Journal of Business and Management, Vol. 3, No. 4.

Goldsmith, R. W. (1969). Financial Structure and Development, New Haven, Yale University Press.

Gujarati, D. N. \& Porter, D. C. (2009). Basic Econometrics, Boston, McGraw-Hill.

Gunderson, G. (1976). A New Economic History of America, New York, McGraw-Hill Book Coy.

Hassan, M. K., Sanchez, B. \& Yu, S. J. (2011). Financial Development and Economic Growth: New Evidence from Panel Data, The Quarterly Review of Economics and Finance, Vol. 51. http://dx.doi.org/10.1016/j.qref.2010.09.001

Igbodaro, C. A.U \& Oriakhi, D. E. (2011). Trivariate Causality Relationship Between Financial Development and Economic Growth In Nigeria, Journal of Banking, Vol. 5, No. 1, (June).

Kemp, T. (1978). Historical Patterns of Industrialization, New York, Longman.

Kiran, B., Yavus, N.C. \& Guris, B. (2009). Financial Development and Economic Growth: A Panel Data Analysis of Emerging Countries, International Research Journal of Finance and Economics, Vol. 30.

Livine, R. \& Zervos, S. (1998). Stock Markets, Banks and Economic Growth, American Economic Review, Vol. 88.

Levine, R. (1997). Financial Development and Economic Growth: Views and Agenda, Journal of Economic Literature, Vol. xxxv.

Maddala, G. S. (2007). Introduction To Econometrics, New Delhi, John Willey.

Mckinnon, R. I. (1973). Money and Capital In Economic Development, Washington D.C.; Brookings Institution.

Meier, G. M. \& Baldwin, R. (1980). Economic Development: Theory, History, Policy, New York, John Wiley.

Murty, K. S., Saihaja, K. \& Demissie, W. M. (2012). The Long-Run Impact of Bank Credit on Economic Growth In Ethiopia: Evidence from Johansen's Multivariate Co-Integration Approach, European Journal of Business and Management, Vol. 4, No. 14.

Ngai, H. (2005). Bank Credit and Economic Growth in Macao, Monetary Authority of Macao. Retrieved on 21/07/2011 from www.amcm.gov.mo/publication. 
Nuno, C. L. (2012). Bank Credit and Economic Growth: A Dynamic Panel Data Analysis, The Economic Research Guardian, Vol. 2, No. 2,

Nwakanma, P. C. \& Nnamdi, I. S. (2012). Corporate Sectoral Investments and Economic Growth in Nigeria: Evidence from The Capital Market, Journal of Business Administration Research, Vol. 1, No. 2, (December). http://dx.doi.org/10.5430/jbar.vln2p99

Obamuyi, M. O. Edun, A. T. \& Kayode, O. F. (2012). Bank Lending, Economic Growth and The Performance of The Manufacturing Sector In Nigeria, European Scientific Journal, Vol. 8, No. 3 (Feb.).

Okereke, E. J. \& Anyanwu, G. I. (2008). Macro Economic Behaviour and Deposit Money (Commercial) Bank Lending In Nigeria (1970 - 2008), The Nigerian Journal of Financial Research Vol. 6, No. 1.

Okpara, G. C. (2010) ${ }^{\text {a }}$. Relative Potency of Financial Repression and Liberalization on Financial Development and Economic Growth: An Empirical Survey, American Journal of Scientific and Industrial Research, http://dx.doi.org/10.5251/ajsir.2010.1.3.643.650

Okpara, G. C. (2010) ${ }^{\mathrm{b}}$. The Effect of Financial Liberalization on Selected Macroeconomic Variables: Lesson from Nigeria, The International Journal of Applied Economics and Finance, Vol. 4, Issue 2. http://dx.doi.org/10.3923/ijaef.2010.5361

Okpara, G. C. \& Nwaoha, W. C. (2010). Government Expenditure, Money Supply, Prices and Output Relationship in Nigeria: An Econometric Analysis, International Research Journal of Finance and Economics Issues 54. [Online] Available: http://www.eurojournals.com/finance.htm

Onuorah, A. C. \& Ozurumba, B. A. (2013). Bank Credits: An Aid to Economic Growth In Nigeria, Information and Knowledge Management, Vol.3, No. 3.

Patrick, H. T. (1976). Demand Following or Supply Leading Finance, In Meier, G. M. (ed), Leading Issues In Economic Development, New York, Oxford University Press.

Pesaran, H. M. \& Shin, Y. (1996). Autoregressive Distributed Lag Modelling To Co-Integration Analysis, DAE Working Paper Series, No. 9514, Department of Applied Economics, University of Cambridge.

Pesaran, H. M. and Pesaran, C. (2001). Bound Testing Approach To The Analysis of Level Relationships, Journal of Applied Econometrics, Vol. 16. http://dx.doi.org/10.1002/jae.616

Popkova, E. G., Shakhovskaya, L. S. \& Mitrakhovich, T. N. (2010). New Quality of Economic Growth Concepts, International Journal of Economic Policy Studies, Vol. 5, Article 5.

Parkash, P. R. (2009). The Nexus Between Financial Development and Economic Growth in India: Evidence from Multivariate VAR Model, International Journal of Research and Reviews in Applied Sciences, Vol. 1, Issue 2.

Robinson, J. (1952). The Generalization of The General Theory, In The Rate of Interest and Other Essays, London, Oxford University Press.

Sanusi, L. S. (2011). Banks In Nigeria and National Economic Development: A Critical Review, Being a Keynote Address at the Seminar on "Becoming An Economic Driver While Applying Banking Regulations", Organized by the Canadian High Commission In Joint Collaboration with the Chartered Institute of Bankers of Nigeria (CIBN) and The Royal Bank of Canada (RBC), (March 7).

Schumpeter, J. A. (1934). The Theory of Economic Development, Cambridge Mass, Harvard University Press.

Shabri, M. \& Majid, A. (2008). Does Financial Development Matter For Economic Growth In Malaysia?: An ARDL Bound Testing Approach, Journal of Economic Cooperation, Vol. 29.

Shaw, E. S. (1973). Financial Deepening in Economic Development, New York, Oxford University Press.

Shaw, E. S. (1976). Financial Repression and Liberalization, In Meier, G. M. (ed) Leading Issues In Economic Development, New York, Oxford University Press.

Sims, C. A. (1972). Money, Income and Causality, American Economic Review, Vol. 62.

Upender, M. (2004). Applied Econometrics, Delhi, Vrinda Publications.

Vittas, D. \& Cho, Y. J. (1996). Credit Polices: Lessons from Japan and Korea, World Bank Research Observer, Vol. 11. No.2, (August). http://dx.doi.org/10.1093/wbro/11.2.277 